\title{
Alkaline phosphatase activity and regulation in the North Pacific Subtropical Gyre
}

\author{
Solange Duhamel,a,c,* Sonya T. Dyhrman,,bc and David M. Karla,c \\ a Department of Oceanography, School of Ocean and Earth Science and Technology (SOEST), University of Hawaii, Honolulu, Hawaii \\ b Biology Department, Woods Hole Oceanographic Institution, Woods Hole, Massachusetts \\ c Center for Microbial Oceanography: Research and Education (C-MORE)
}

\begin{abstract}
Alkaline phosphatase (AP) activity (APA) was measured at several stations in the North Pacific Subtropical Gyre in July 2008, and in a series of nutrient addition experiments: nitrate plus ammonium (+N) or phosphate $(+\mathrm{P})$, to study APA regulation and to evaluate the capacity of picoplankton organisms (i.e., in the $0.2-2-\mu \mathrm{m}$ size range) to access the AP-hydrolyzable fraction of dissolved organic phosphorus (DOP). The data indicated a primary limitation of the biomass by nitrogen. Both total (measured with a soluble DOP analog) and cell-specific (measured with the enzyme-labeled fluorescence [ELF] phosphate cell labeling method) APA were enhanced in the $+\mathrm{N}$ samples and reduced in the $+\mathrm{P}$ samples, suggesting that DOP is an important resource for picoplankton nutrition. Cell-free APA represented $>65 \%$ of the APA in all samples, but its contribution to total APA significantly decreased in the $+\mathrm{N}$ treatment as microbial biomass increased. In the $+\mathrm{N}$ treatment, $<5 \%$ and up to $96 \%$ of the cells in the heterotrophic bacteria-enriched and picophytoplankton-enriched fractions, respectively, were ELF-alcohol-labeled after $5 \mathrm{~d}$. Following $\mathrm{N}$ enrichment, the microbial assemblage shifted from cell-free phosphatase dominated under $\mathrm{N}$ limitation and $\mathrm{P}$ stress (i.e., physiological response) to picophytoplankton-based phosphatase dominated under P limitation (i.e., production or growth rate limitation). If, as predicted, the ocean evolves towards P limitation, DOP availability would become of major importance to sustain productivity.
\end{abstract}

Phosphorus (P), generally in the form of phosphate, is an essential nutrient for life (Karl 2000). P availability in the ocean is considered to have a predominant role in controlling planktonic biomass and production (Karl et al. 2001; Van Wambeke et al. 2002; Moutin et al. 2008). Among the $\mathrm{P}$ reservoirs in the ocean, dissolved inorganic $\mathrm{P}$ (DIP) is directly incorporated by microorganisms whereas dissolved organic P (DOP) must generally be enzymatically hydrolyzed to release DIP that can be transported and incorporated into the cell. There are many enzymes that hydrolyze DOP (e.g., phosphodiesterases, phosphomonoesterases, and phosphonatases, to name a few), but alkaline phosphatase (AP) is the best studied and arguably the most important for nutrition, because it has the potential to hydrolyze a broad spectrum of DOP compounds (e.g., the phosphomonoesters) and is produced by a majority of marine heterotrophic bacteria and phytoplankton (Cembella et al. 1984; Hoppe 2003). Consequently, AP plays a prominent role in the recycling of organic P. AP activity (APA) has been shown to be regulated by DIP supply (Cembella et al. 1984) and is thus considered to be an indicator of P stress or P limitation (Hoppe 2003; Dyhrman and Ruttenberg 2006; Nedoma et al. 2006). P stress is defined as a physiological response to a low level of P: the organisms may up-regulate proteins or enzymes to aid in $\mathrm{P}$ scavenging but at this stage the production rate is not $\mathrm{P}$ limited and is sustained. The extent to which these Pstressed cells are able to scavenge $\mathrm{P}$ will result in either $\mathrm{P}$ limitation or recovery (Beardall et al. 2001; Dyhrman and Ruttemberg 2006). Production or growth rate limitation is a later stage of nutrient starvation wherein the organisms cannot reach their nutrient needs and the biomass will

\footnotetext{
*Corresponding author: solange@hawaii.edu
}

consequently be reduced (Van Wambeke et al. 2002; Nedoma et al. 2006). Nevertheless, APA is not necessarily an unequivocal indicator of $\mathrm{P}$ stress because it can be constitutive, it is not universal to all microorganisms, and it is expressed in deep ocean waters where DIP concentrations are high (for review, see Hoppe 2003). The distribution of APA is highly variable and can be found in both the particulate (i.e., $>0.2 \mu \mathrm{m}$ ) and the dissolved (i.e., $<0.2 \mu \mathrm{m}$ ) fractions of seawater. In many marine ecosystems, the contribution of the dissolved fraction can be high (> 70\%; Hoppe 2003).

DIP concentrations have been shown to be limiting in various marine systems, and many oligotrophic habitats seem to be particularly prone to severe P-limiting conditions (Karl 2000). Because DOP concentrations often exceed DIP concentrations in surface waters, this pool is increasingly recognized as being important to sustaining microbial growth by providing an alternative $\mathrm{P}$ source (Orrett and Karl 1987; Karl and Björkman 2002). Therefore, regeneration of DIP by enzymatic hydrolysis from the DOP may be essential to the plankton. Expected increases in $\mathrm{CO}_{2}$ levels and temperature in the future ocean may lead to an increase in global dinitrogen $\left(\mathrm{N}_{2}\right)$ fixation, fundamentally altering the current marine nitrogen $(\mathrm{N})$ cycle and potentially driving some oceanic regimes towards $\mathrm{P}$ stress and increasing demand for DOP (Karl 1999; Karl et al. 2001; Hutchins et al. 2007). As such, the extent to which microbes are able to access the hydrolyzable DOP reservoir will drive the capacity of the ocean to sustain productivity under conditions of DIP stress. This process is particularly important for oligotrophic environments, which cover more than $75 \%$ of the global ocean surface and contribute to approximately $80 \%$ of the total oceanic production (Ryther 1969). In such environments, free- 


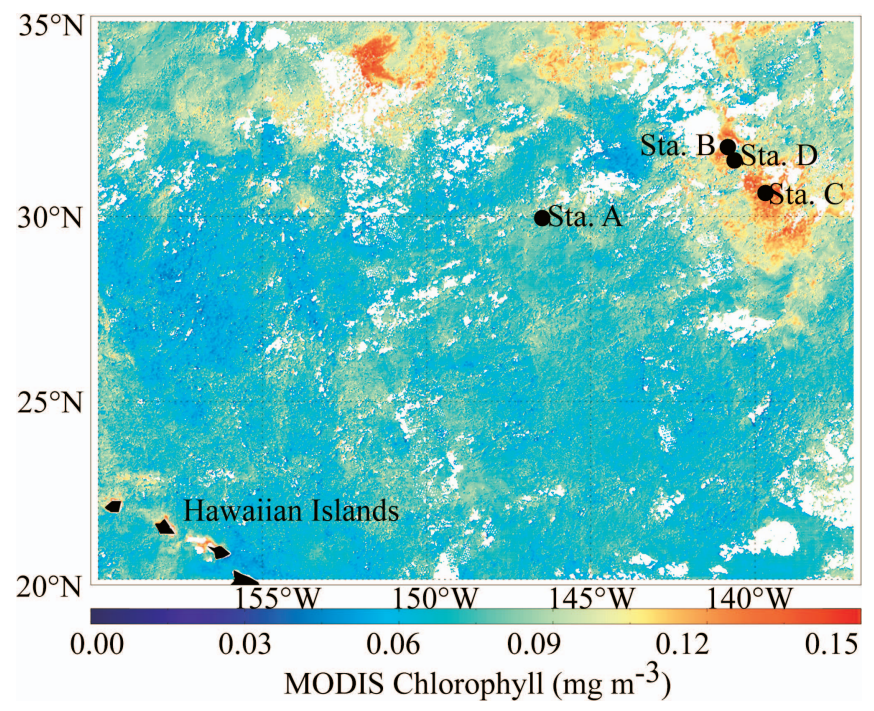

Fig. 1. Station locations on average MODIS chlorophyll for 30 June-07 July. White areas have no data because of cloud cover. Figure credit: Cara Wilson.

living picoplankton (i.e., heterotrophic prokaryotes, hereafter termed bacteria, and autotrophic prokaryotes and eukaryotes, hereafter named phytoplankton, in the $0.2-2$ $\mu \mathrm{m}$ size range: Prochlorococcus, Synechococcus, and picoeukaryotes) are predominant in abundance, biomass, and production (Agawin et al. 2000). The aims of this study were to investigate the $\mathrm{P}$ status (i.e., $\mathrm{P}$ stress or limitation) and APA regulation capacity of picoplankton groups from the North Pacific Subtropical Gyre (NPSG) to better understand nutrient controls and stress or limitation responses of natural picoplankton populations, and to determine P-related responses to increased $\mathrm{N}$ supply predicted with future ocean climate interactions. The contribution of APA in the dissolved fraction and its variations with nutrient status was also investigated.

\section{Methods}

Field site-Seawater samples were collected during the Pacific Open Ocean Bloom cruise in July 2008. One of the goals of this cruise was to study summer phytoplankton blooms occurring in the subtropical front of the NPSG (between approximately $30^{\circ}$ and $32^{\circ} \mathrm{N}$ ). We used moderate resolution imaging spectroradiometer (MODIS) satellite images to locate a patch of high chlorophyll $a$ (Chl a) associated with a summer phytoplankton bloom. Samples were taken at four stations: Sta. A-D (Fig. 1). Sta. A was located outside of the patch of elevated Chl $a$ that was observed by satellite images (Fig. 1), and Sta. B-D were located within the patch. Physicochemical characteristics of the four stations are listed in Table 1. Samples corresponding to a photosynthetically active radiation (PAR) level of $50 \%$ of surface irradiance (typically, 15-20 m) were taken in the study area using Niskin ${ }^{\circledR}$ type polyvinyl chloride bottles. The PAR was determined using a biospherical sensor attached on the conductivity-temperature-depth rosette frame. Samples were collected into acid-cleaned
$(10 \% \mathrm{HCl})$ bottles rinsed three times with sample water prior to analysis.

Nutrient addition experiments - Nutrient addition experiments were conducted at Sta. A and D. Water was prescreened through $202-\mu \mathrm{m}$ Nitex ${ }^{\circledR}$ mesh to remove large zooplankton and collected into acid-cleaned $(10 \% \mathrm{HCl}) 4-$ liter polycarbonate carboys rinsed three times with sample. Nine replicate carboys were prepared for each treatment, corresponding to (1) control (Ctrl, not amended), (2) Namended $\left(+\mathrm{N}, 3 \mu \mathrm{mol} \mathrm{L}^{-1}\right.$ dissolved inorganic $\mathrm{N}$ as equimolar additions of $\mathrm{NaNO}_{3}$ plus $\mathrm{NH}_{4} \mathrm{Cl}$ ), and (3) phosphate-amended (+P, $1 \mu \mathrm{mol} \mathrm{L}{ }^{-1}$ DIP as $\left.\mathrm{KH}_{2} \mathrm{PO}_{4}\right)$. These concentrations were chosen to be at least an order of magnitude larger than expected surface concentrations. A set of triplicate samples was also prepared to measure initial conditions. Each treatment $(\mathrm{Ctrl},+\mathrm{N}$, and $+\mathrm{P})$ was incubated and sampled on days 1, 3, and 5. At each time point, triplicate randomized carboys of each treatment were analyzed and sacrificed in order to avoid perturbation and possible contamination by resampling. Each treatment was sampled for total and cell-specific APA, cell abundance, and $\mathrm{Chl} a$ and $\mathrm{P}$ stocks concentrations.

Nutrient analysis-DIP concentrations were determined on triplicate $50-\mathrm{mL}$ samples by the magnesium-induced coprecipitation (MAGIC) method (Karl and Tien 1992) followed by the molybdenum blue reaction (Murphy and Riley 1962). Total dissolved $\mathrm{P}$ was measured as described elsewhere (Björkman et al. 2000) and DOP estimated as (total dissolved P - DIP). AP-hydrolyzable DOP was measured according to the method of Strickland and Parsons (1972) based on P release by adding Escherichia coli AP (EC 3.1.3.1). Triplicate 50-mL samples were incubated with $1 \mathrm{~mL}$ of Tris buffer solution $(\mathrm{pH} 8.00)$ and $1 \mathrm{~mL}$ of $E$. coli AP (EC 3.1.3.1, Worthington Biochemical Corporation) solution $\left(1\right.$ unit $\left.\mathrm{mL}^{-1}\right)$ at $30^{\circ} \mathrm{C}$ for $2 \mathrm{~h}$. DIP concentrations were determined by the MAGIC method before and after the enzyme treatment to determine the concentration of DIP released with hydrolysis and obtain AP-hydrolyzable DOP concentrations. Glucose-6-phosphate was used for calibration and enzyme efficiency controls. For each series of measurements, a triplicate blank was prepared from the resulting supernatant obtained after the enzymatic and MAGIC precipitation treatments and was processed as a regular sample. All $\mathrm{P}$ analyses were corrected for arsenate interference (Johnson 1971) and measured by absorption spectrophotometry (880 nm; Beckman DU $\left.{ }^{\circledR 640}\right)$.

Picoplankton analysis - Chl a was measured on 200-mL samples collected onto 0.2 - and $0.6-\mu \mathrm{m}$-porosity polycarbonate filters (47-mm diameter), using $100 \%$ acetone extraction and a Turner 10-AU fluorometer. Samples for picoplankton enumeration were fixed in a final concentration of $0.2 \%$ paraformaldehyde, flash-frozen in liquid $\mathrm{N}$, and stored at $-80^{\circ} \mathrm{C}$. In addition to a whole water sample, $<0.6$ $\mu \mathrm{m}$ samples (corresponding to the filtrate from the $0.6-\mu \mathrm{m}$ filtered sample) were also prepared for each treatment. Picophytoplankton and heterotrophic bacterial abundances 
Table 1. Physicochemical and microbiological characteristics (average $\pm \mathrm{SD}, n=3$ ) for the four sites sampled: Sta. A-D. The precision of the nitrate + nitrite concentration was $3 \%$.

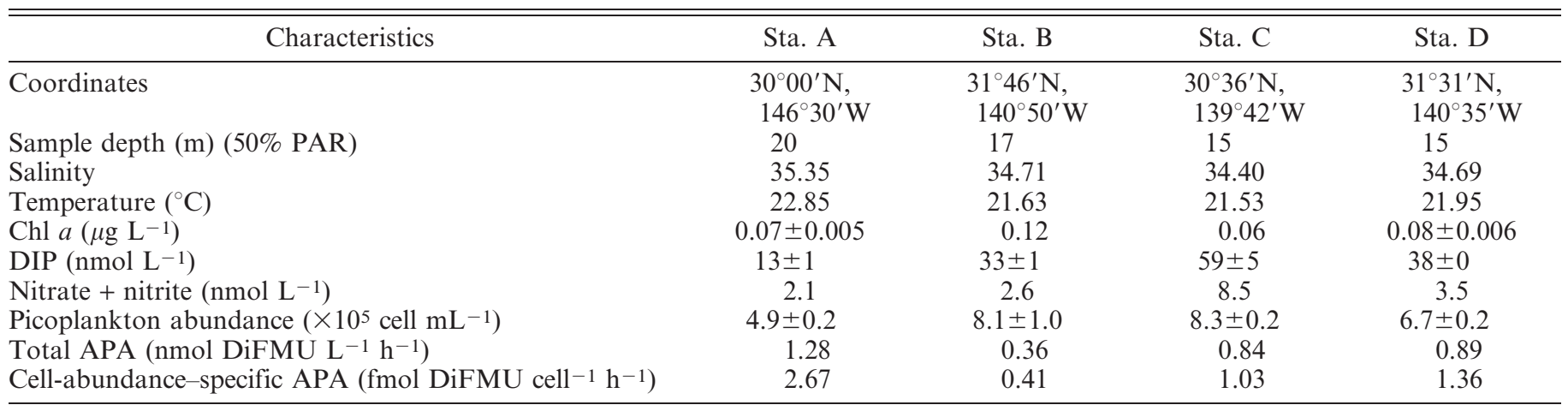

were determined using a Cytopeia Influx flow cytometer. Samples were processed according to Marie et al. (2000).

$A P A$-Total APA was measured using the fluorogenic phosphatase substrate 6,8-difluoro-4-methylumbelliferyl phosphate (DiFMUP, Molecular Probes), at a final concentration of $2 \mu \mathrm{mol} \mathrm{L}-1$ (saturating, data not shown). Four types of samples were analyzed to separate activity due to total (20 mL of total sample), dissolved ( $20 \mathrm{~mL}$ of $<0.2-\mu \mathrm{m}$ sample), heterotrophic bacteria-enriched, and phytoplankton-enriched fractions. Heterotrophic bacteria-enriched fraction corresponded to $20 \mathrm{~mL}$ sample filtered on a $0.2-\mu \mathrm{m}$ polycarbonate filter, whereas phytoplankton-enriched fraction was prepared from $500 \mathrm{~mL}$ sample collected on a 0.6$\mu \mathrm{m}$-porosity polycarbonate filter. Because the large majority of the cells found in the $0.6-\mu \mathrm{m}$ phytoplankton-enriched fraction were smaller than $2 \mu \mathrm{m}$, this fraction is reported as the picophytoplankton-enriched fraction, and is likely dominated by Synechococcus. The filters were put in $4 \mathrm{~mL}$ of filtered, boiled seawater (natural $0.2-\mu \mathrm{m}$-filtered seawater, collected at the same stations, boiled for $1 \mathrm{~min}$ and cooled before use) and thus all assays were done in the presence of ambient DIP. All samples were incubated in the dark at in situ temperature in a water bath. Hydrolysis of DiFMUP to 6,8-difluoro-7-hydroxy-4-methylcoumarin (DiFMU) was measured on a Perkin Elmer LS-5 luminescence spectrometer at room temperature (excitation and emission: 359 and $449 \mathrm{~nm}$ ). At least four measurements were obtained within $12 \mathrm{~h}$ (the linearity of the assay was verified). A standard curve from 0 to $4.5 \mu \mathrm{mol} \mathrm{L}^{-1}$ in filtered, boiled seawater was used to calculate DiFMUP hydrolysis rates. Blanks (i.e., ultrapure water) and killed controls (i.e., sample fixed with $0.2 \%$ paraformaldehyde [final concentration]) were run periodically and indicated no significant autohydrolysis of the substrate. The filtered, boiled seawater was also periodically assayed to control for possible dissolved APA and showed no significant hydrolysis of the substrate. We report cellabundance-specific APA corresponding to DiFMUP hydrolysis rates normalized to cell abundance.

Samples for cell-specific APA were assayed with enzymelabeled fluorescence (ELF) phosphate (ELFP) as previously described (Duhamel et al. 2008; Van Wambeke et al. 2008). Briefly, 20- and 500-mL samples were filtered onto black 0.2and white $0.6-\mu \mathrm{m}$ polycarbonate filters, respectively, for the heterotrophic bacteria- and picophytoplankton-enriched fractions, respectively. As suggested by previous studies, dim Prochlorococcus autofluorescence prevents quantitative enumeration by epifluorescence microscopy, and its abundance could bias bacterial and picophytoplankton counts. Flow cytometry counts were thus systematically processed on a whole and on $<0.6-\mu \mathrm{m}$ samples in order to determine Prochlorococcus contribution to the $0.6-\mu \mathrm{m}$ filter. Results showed that $>70 \%$ of the Prochlorococcus cells were present in the fraction smaller than $0.6 \mu \mathrm{m}$. Prochlorococcus may represent $5-19 \%$ of the total counts on the $0.2-\mu \mathrm{m}$ (i.e., the heterotrophic bacteria-enriched) fraction. Each filter was put on a microscopy slide and $40 \mu \mathrm{L}$ of the 1:20 diluted ELFP solution (E 6601, Molecular Probes) was spread onto the filter. The incubation time was determined according to kinetics made on initial samples as described elsewhere (Duhamel et al. 2009). The reaction was stopped with a solution of phosphate-buffered saline $\left(10 \mathrm{mmol} \mathrm{L}^{-1}, \mathrm{pH} 7.5\right)$ with $1 \%$ formaldehyde, for $15 \mathrm{~min}$ (in the dark). Cells on $0.2-$ $\mu \mathrm{m}$ filters were counterstained with 4',6-diamidino-2-phenylindole (DAPI, $2.5 \mu \mathrm{g} \mathrm{mL}^{-1}$ final concentration; Duhamel et al. 2008). The filter was then mounted with immersion oil onto a glass slide for microscopic analysis. Heterotrophic bacteria and phytoplankton cells were identified using a Nikon Eclipse E600 microscope. Phytoplankton cells were identified using a Chl $a$ filter set and heterotrophic bacteria were identified using a DAPI long pass filter set. The cells were scored as positive or negative according to the presence or absence of the green ELF-alcohol (ELFA) precipitates, resulting from the ELFP hydrolysis, using a DAPI long pass filter set.

Statistical analysis - One-way analysis of variance (ANOVA) was performed to compare between initial conditions and days 1,3 , and 5 , and significance is reported where $p \leq 0.05$. Pairwise comparisons between treatments and controls were performed using a $t$-test, and significance is reported where $p \leq$ 0.05. Analyses were made using SigmaStat 3.1 software.

\section{Results}

Four stations were sampled for total APA, picoplankton abundances, and Chl $a$ and DIP concentrations (Table 1). According to satellite images (Fig. 1, average MODIS 
chlorophyll for 30 June-7 July), a high-Chl $a$ patch had developed at Sta. B-D, whereas Sta. A was outside this patch. However, when visiting these stations on July 5 and July 14 for Sta. A and Sta. D, respectively, Chl $a$ concentrations measured at both stations were similar (Table 1). Nevertheless, picoplankton cell abundances were significantly higher at Sta. D (Table 1). Results from silicon biomass and uptake measurements show that the bloom was probably in decline (J. Krause and M. Brzezinski pers. comm.), explaining the lower Chl $a$ measured at Sta. B-D than expected from the prior week's satellite images. The high-Chl $a$ patch detected by ocean color satellite images, between 30 June and 7 July, was located in the surrounding area of the northern subtropical front of the NPSG. The position of the subtropical front was defined from temperature-salinity diagrams. Sta. B and D were located outside the transition zone (i.e., north of the front), whereas Sta. C was in the transition zone. Sta. B showed the highest Chl a concentration (Table 1). The total APA was normalized to picoplankton (i.e., heterotrophic bacteria plus picophytoplankton enumerated by flow cytometry) cell abundance (i.e., cell-abundance-specific APA; Table 1). Sta. A had the highest cell-abundance-specific APA value (2.67 fmol DiFMU cell $\left.{ }^{-1} \mathrm{~h}^{-1}\right)$ and the lowest DIP concentration and picoplankton cell abundance values $\left(13 \pm 1 \mathrm{nmol} \mathrm{P} \mathrm{L}{ }^{-1}\right.$ and $4.9 \pm 0.2 \times 10^{5}$ cell $\left.\mathrm{mL}^{-1}\right)$. Sta. B, which had the highest $\mathrm{Chl} a$ concentration and picoplankton abundance values $\left(8.1 \pm 1.0 \times 10^{5}\right.$ cell $\left.\mathrm{mL}^{-1}\right)$, also had the lowest cell-abundance-specific APA value $(0.41 \mathrm{fmol}$ DiFMU cell $\left.{ }^{-1} \mathrm{~h}^{-1}\right)$, whereas DIP concentration (33 \pm 1 nmol $\mathrm{P} \mathrm{L}^{-1}$ ) was intermediary to those found at other stations. Sta. C and Sta. D were characterized by higher DIP concentrations ( $59 \pm 5$ and $38 \pm 0$ nmol $\left.\mathrm{P} \mathrm{L} \mathrm{L}^{-1}\right)$ and lower Chl $a$ values falling in the range of that measured at Sta. A. The cell-abundance-specific APA values were intermediary to those observed at Sta. A and Sta. B (1.03 and 1.36 fmol DiFMU cell ${ }^{-1} \mathrm{~h}^{-1}$ for Sta. C and Sta. D, respectively).

Changes in APA were characterized outside and inside the high Chl $a$ patch detected by ocean color satellite images, by conducting nutrient-addition experiments at Sta. A and Sta. D, respectively, at depths corresponding to $50 \%$ of surface PAR (i.e., 20 and $15 \mathrm{~m}$ for Sta. A and Sta. $\mathrm{D}$, respectively; Table 1). Although Sta. D had slightly lower salinity and temperature values $\left(34.69\right.$ and $21.95^{\circ} \mathrm{C}$, respectively) than Sta. A (35.35 and $22.85^{\circ} \mathrm{C}$, respectively), it had higher Chl $a$, picoplankton abundances, DIP, and nitrate + nitrite concentrations $(0.08 \pm 0.006 \mu \mathrm{g} \mathrm{L}-1,6.7 \pm$ $0.2 \times 10^{5}$ cell $\mathrm{mL}^{-1}, 38 \pm 0 \mathrm{nmol} \mathrm{L}-1$, and $3.5 \mathrm{nmol} \mathrm{L}-1$, respectively) than Sta. A $(0.07 \pm 0.005 \mu \mathrm{g} \mathrm{L}-1,4.9 \pm 0.2 \times$

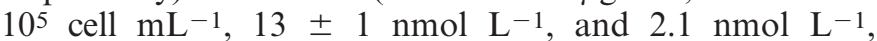
respectively; Table 1).

In both incubation experiments there was a significant increase in Chl $a$ concentration (by factors of 5.3 and 5.5 for Sta. A and Sta. D, respectively) in the $+\mathrm{N}$ treatment compared to the initial conditions, with maximum values reached after $5 \mathrm{~d}\left(0.37 \pm 0.05 \mu \mathrm{g} \mathrm{L} \mathrm{L}^{-1}, p=0.002\right)$ for Sta. A and after $3 \mathrm{~d}\left(0.44 \pm 0.07 \mu \mathrm{g} \mathrm{L}^{-1}, p=0.005\right)$ for Sta. D (Fig. 2C,D) of incubation. The maximum Chl $a$ concentrations obtained at both stations were not significantly different $(p=0.284)$. The Chl $a$ concentrations reached in the $+\mathrm{N}$ treatment were significantly higher $(p=0.008$ and $p$ $<0.001$ for Sta. A and Sta. D, respectively) than in the Ctrl whereas those from the $+\mathrm{P}$ treatment were not significantly different from the $\operatorname{Ctrl}(p=0.057$ and $p=0.842$ for Sta. A and Sta. D, respectively). No significant difference was measured between the initial sample and the Ctrl at D5 for Sta. A $(p=0.620)$. Nevertheless, at Sta. D, Chl $a$ concentrations measured in the Ctrl after $3 \mathrm{~d}(0.08 \pm$ $\left.0.01 \mu \mathrm{g} \mathrm{L}^{-1}\right)$ were lower $(p=0.046)$ than in the initial

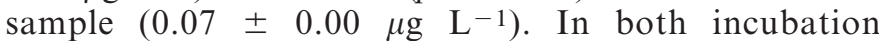
experiments, picoplankton total abundances significantly decreased with incubation time between the initial and control samples $(p<0.05)$, because of a reduction in heterotrophic bacteria and Prochlorococcus abundances, over extended incubation.

Cell-abundance-specific APA also increased significantly in the $+\mathrm{N}$ treatment relative to the control, with maximum values reached at day 5 for both stations $(52.7$ \pm 2.1 and $27.9 \pm 9.6 \mathrm{fmol} \mathrm{cell}^{-1} \mathrm{~h}^{-1}$ for Sta. A and Sta. D, respectively; Fig. 2A,B), whereas no significant change was observed in the $+\mathrm{P}$ treatment relative to the $\mathrm{Ctrl}(p=0.087$ and 0.948 for Sta. A and Sta. D, respectively). The cellabundance-specific APA reached values significantly higher at Sta. A $(p=0.002)$ where the lower initial DIP concentrations were found. Indeed, at both stations, DIP concentrations decreased with time in the Ctrl and $+\mathrm{N}$ treatments, but the initial DIP concentrations were three times higher at Sta. D $(p<0.001$; Fig. 2G,H). DIP concentrations increased with incubation time in the $+\mathrm{P}$ treatments at Sta. A (Fig. 2G) whereas they decreased at Sta. D (Fig. 2H). The proportion of dissolved APA in both experiments showed approximately the same trend (Fig. 2E,F). Whereas the proportion of dissolved activity was high and stable with time in the Ctrl and $+\mathrm{P}$ treatment, it was lower and significantly decreased with time in the $+\mathrm{N}$ treatment when expressed as a proportion of total activity (ANOVA: $p=0.007$ and $p=0.002$ for Sta. A and Sta. D, respectively). At day 5, when cell-abundance-specific APA was maximum, the proportion of dissolved activity in the $+\mathrm{N}$ treatment represented $43 \% \pm 16 \%$ and $41 \% \pm 9 \%$ of the total APA at Sta. A and Sta. D, respectively, whereas the proportion of dissolved activity in the control and $+\mathrm{P}$ treatments represented $67 \% \pm 14 \%$ to $115 \% \pm 29 \%$ of the total APA (Fig. 2E,F).

APA was also studied by concentrating particles on two types of filters: $20 \mathrm{~mL}$ of whole water sample filtered onto a $0.2-\mu \mathrm{m}$ filter to examine APA associated with the heterotrophic bacteria-enriched fraction and $500 \mathrm{~mL}$ of sample filtered onto a $0.6-\mu \mathrm{m}$ filter to examine APA attributable to the picophytoplankton-enriched fraction. Both total and cell-specific APA (with DiFMUP and ELFP, respectively) were measured on these sample preparations. For each experiment, the heterotrophic bacteria-enriched fraction (Fig. 3A,C,E,G) showed increasing values with time for both total (ANOVA: $p=0.022$ ) and cell-specific APA (ANOVA: $p<0.001$ ) in the $+\mathrm{N}$ treatment and reached maximum values after $5 \mathrm{~d}$. The same general trend was observed for the picophytoplanktonenriched fraction. However, in the $+\mathrm{N}$ treatment, whereas 


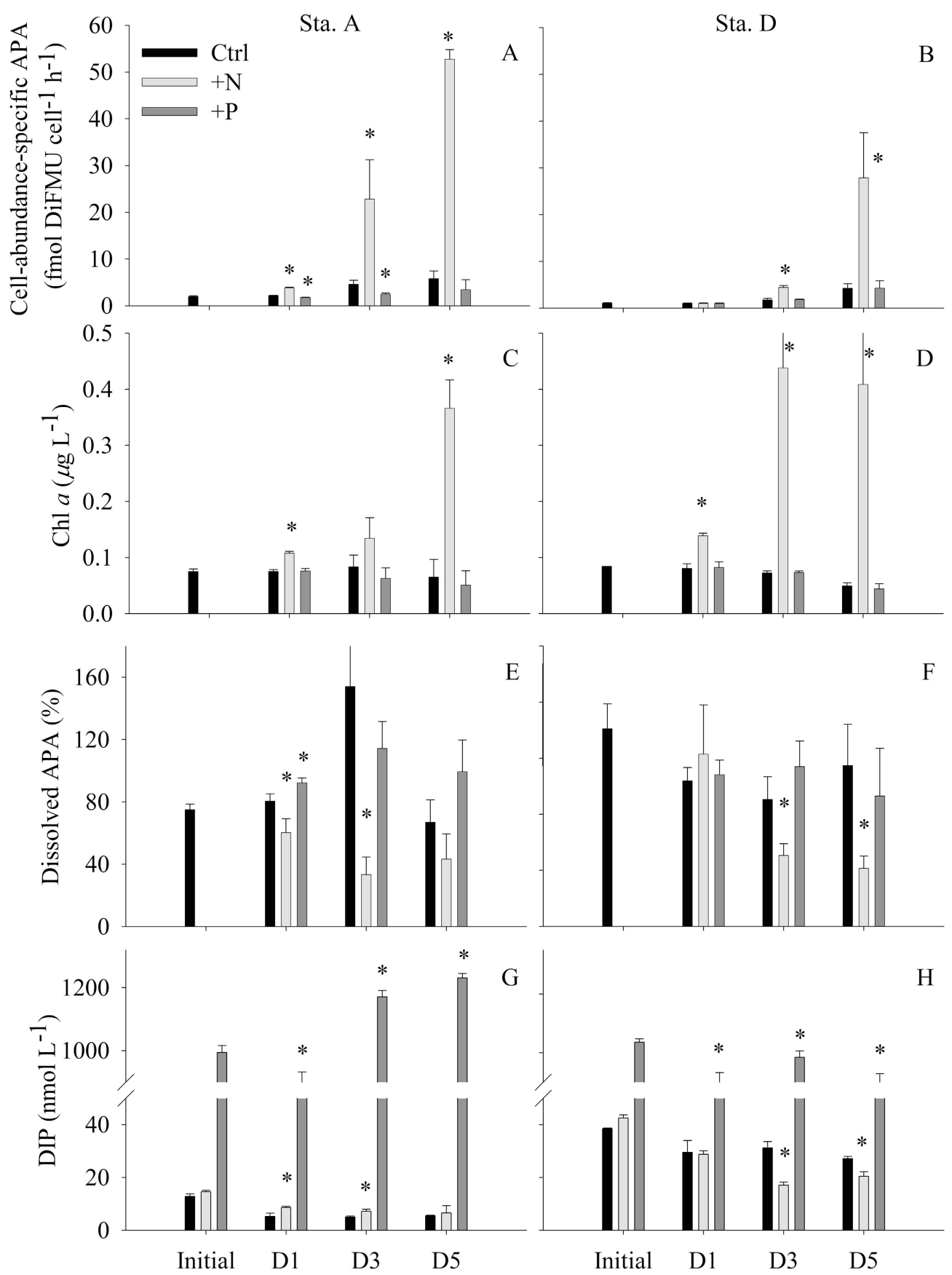

Fig. 2. Plots from the two nutrient addition experiments (Sta. A: plots A, C, E, and G; Sta. D: plots B, D, F, and H). All graphs are plotted with control (Ctrl), nitrogen-amended $(+\mathrm{N})$, and phosphate-amended (+P) treatments for initial conditions and for days 1, 3, and $5(\mathrm{D} 1, \mathrm{D} 3$, and D5, respectively) of incubation. (A, B) Cell-abundance-specific APA, normalized to picoplankton cell abundance; (C, D) chlorophyll $a(\mathrm{Chl} a)$ concentration; (E, F) dissolved APA expressed as a percentage of the total APA; $(\mathrm{G}, \mathrm{H})$ dissolved inorganic phosphate (DIP) concentration. In all cases, error bars denote standard deviations $(n=3)$. Significance $(t$-test, $\mathrm{df}=11, p \leq 0.05)$ is indicated by an asterisk for pairwise comparisons between the $+\mathrm{N}$ or the $+\mathrm{P}$ treatments and the control.

total APA in the picophytoplankton-enriched fraction $(0.79 \pm 0.33$ and $0.69 \pm 0.06$, for Sta. A and Sta. D, respectively) was equal to or lower than $(p=0.333$ and $p=$ 0.049 at Sta. A and Sta. D, respectively) that in the heterotrophic bacteria-enriched fraction $(1.31 \pm 0.09$ and
$2.29 \pm 0.67$, for Sta. A and Sta. D, respectively) after $5 \mathrm{~d}$, the proportion of ELFA-labeled picophytoplankton reached up to 29 times the proportion of ELFA-labeled heterotrophic bacteria. Moreover, the proportion of ELFA-labeled picophytoplankton cells reached significant- 

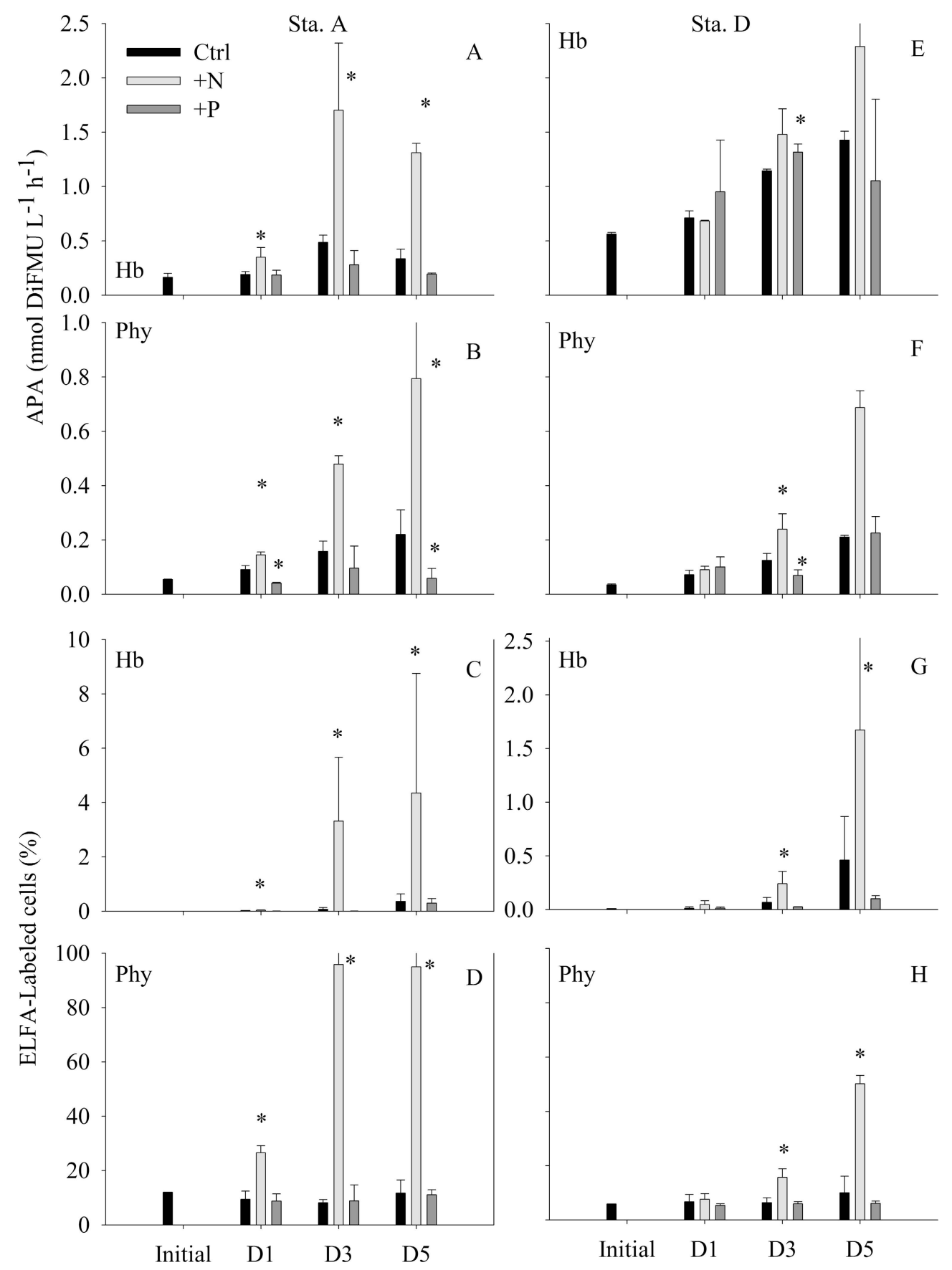

Fig. 3. Plots from the two nutrient addition experiments (Sta. A: plots A, B, C, and D; Sta. D: plots E, F, G, and H). (A, B, E, and F) Alkaline phosphatase activity (APA). (C, D, G, and H) Percentage of ELFA-labeled cells. APA and ELFA-labeled cells are given for the heterotrophic bacteria-enriched fraction (i.e., $\mathrm{Hb}$ on the plots, corresponding to $20 \mathrm{~mL}$ sample filtered on 0.2$\mu \mathrm{m}$ filter) and for the picophytoplankton-enriched fraction (i.e., Phy on the plots, corresponding to $500-\mathrm{mL}$ sample filtered on $0.6-\mu \mathrm{m}$ filter - only the cells smaller than $2 \mu \mathrm{m}$ were taken into account). In all cases, error bars denote standard deviations $(n=3)$. Note the difference in APA scales for heterotrophic bacteria- and picophytoplankton-enriched fractions plots and in ELFAlabeled cells for heterotrophic bacteria-enriched fractions from Sta. A and D. Significance ( $t$-test, $\mathrm{df}=11, p \leq 0.05)$ is indicated by an asterisk for pairwise comparisons between the $+\mathrm{N}$ or the $+\mathrm{P}$ treatments and the control. 
ly lower values $(p=0.001)$ at Sta. $\mathrm{D}(50 \% \pm 3 \%)$ compared to Sta. A $(96 \% \pm 7 \%)$, whereas no significant difference ( $p$ $=0.178$ ) was observed for the heterotrophic bacteriaenriched fraction. At day 5, total and cell-specific APA of both cell fractions were lower than in the Ctrl for the $+\mathrm{P}$ treatments, but the difference was not significant $(p>$ $0.05)$.

\section{Discussion}

Although DIP is readily available for assimilation by microorganisms, its concentration in the surface waters of the open ocean is often lower than $50 \mathrm{nmol} \mathrm{L}^{-1}$, which makes it a potentially limiting factor for net growth. Therefore, microorganisms with the genetic potential to utilize P from the much larger pool of DOP may be at a competitive advantage. Whether microorganisms utilize DOP and, if so, how DOP assimilation is regulated are relevant issues in contemporary marine microbial ecology. As detailed earlier, APA has been used to characterize P stress or limitation in aquatic systems (Nedoma et al. 2003; Dyhrman and Ruttemberg 2006; Duhamel et al. 2008), and to examine these systems for potential utilization of DOP. APA can be studied using soluble substrate analogs that yield soluble (such as DiFMU) or insoluble (such as ELFA) products upon hydrolysis. The utilization of the first family of compounds provides information on the kinetic parameters of the enzyme activity in the whole seawater samples (i.e., total APA), whereas the utilization of the second family provides an identification and quantification of substrate reactive cells (i.e., cell-specific APA). Data from total APA measurements are difficult to compare with other studies because the substrate choice (e.g., 4-methylumbelliferyl phosphate, nitrophenyl phosphate, 3-Omethylfluorescein phosphate, 3,6-fluorescein diphosphate, Attophos, DiFMUP), its concentration (e.g., saturating or not), and even the sample preparation methods (e.g., different volume of the whole or filtered sample, different filter pore size, presence or absence of ambient P) vary widely among studies (Table 2). Moreover, there is a wide range of total microbial biomass encountered in systems ranging from oligotrophic open ocean systems to eutrophic coastal systems such that total APA measurements are difficult to compare unless total cell numbers or biomass is also reported.

In this study, both total and cell-specific APA were measured. APA was present at all stations and corresponds to the lower range of values typically measured in oligotrophic environments (Table 2). Nevertheless, considering the DIP uptake rates measured at the same stations with a ${ }^{32} \mathrm{P}$-DIP tracer $\left(0.24\right.$ and $0.12 \mathrm{nmol} \mathrm{L}^{-1} \mathrm{~h}^{-1}$ at Sta. $\mathrm{A}$ and Sta. D, respectively, data not shown), the DIP released from APA could fulfill $\mathrm{P}$ needs at both stations if the APA-hydrolyzable fraction of the DOP were in sufficient concentration (here a supply rate of 2.88$5.76 \mathrm{nmol} \mathrm{L}^{-1} \mathrm{~d}^{-1}$ ). APA-hydrolyzable DOP concentrations assayed in this study were below the detection limit of the method (i.e., $<5 \mathrm{nmol} \mathrm{L}^{-1}$ ). Regardless of the standing stock, it is well known that DOP is also produced during DIP assimilation within complex open ocean food webs
(Orrett and Karl 1987), so the daily supply of bioavailable DOP (including phosphomonoesters) can easily exceed the ambient concentration at any given time. It is reasonable to assume that bioavailable DOP compounds, including phosphomonoesters, could be rapidly cycled and present at low to undetectable concentrations if they are important sources of $\mathrm{P}$ for the microbial community.

Measuring the presence of APA alone, without complementary data on the physiological or genetic regulation of this enzyme, makes interpretation of the nutrient status of the population challenging (Karl and Björkman 2002; Dyhrman and Ruttenberg 2006). To answer this question, we conducted 5-d incubations in 4-liter enclosures with different nutrient amendments. Studies using incubation of water samples under conditions that simulate natural conditions have shown changes in growth, in activity, and in taxon composition (ZoBell 1943; Agis et al. 2007). Recent studies also showed contradictory results (Hammes et al. 2010). Comparing Chl $a$ concentration and picoplankton abundances in the initial and control samples, we found either no significant change or a decrease over $5 \mathrm{~d}$, further highlighting the challenges associated with incubating natural populations over an extended period. Nitrate plus ammonium amendments (i.e., $+\mathrm{N}$ treatment) were used to force community drawdown of DIP by the coupled incorporation of $\mathrm{N}$ plus $\mathrm{P}$ into biomass. In this treatment, cell-abundance-specific APA increased by factors of 27.5 and 26.3 between initial conditions and day 5 for experiments conducted at Sta. A and Sta. D, respectively, underlining a large capacity for regulation of the community APA. If the predictions that the ocean may be evolving towards a system with increased $\mathrm{N}_{2}$ fixation and resultant $\mathrm{P}$ limitation (Karl et al. 2001; Barcelos e Ramos et al. 2007; Hutchins et al. 2007) are correct, our results suggest that APA will be an important process in $\mathrm{P}$ acquisition in the future ocean. This also underscores that ambient phosphomonoester concentration is sufficient to meet $\mathrm{P}$ demand in these experiments. In the $+\mathrm{P}$ treatments, APA significantly decreased compared to the control (Figs. 2, 3), indicating that the DIP additions decreased the need for DOP hydrolysis and resulted in a decline in the APA. Although the Chl $a$ biomass increased only in the $\mathrm{N}$ treatment, suggesting biomass $\mathrm{N}$ limitation in the study area, APA was depressed in the $\mathrm{P}$ treatment, suggesting that organisms were under $\mathrm{P}$ stress in situ. In an additional $\mathrm{N}$ plus $\mathrm{P}$ treatment, the $\mathrm{Chl} a$ biomass might have been stimulated more than with $\mathrm{N}$ addition alone. Taken together, these results suggest that in a future ocean scenario of increased $\mathrm{N}_{2}$ fixation and $\mathrm{P}$ demand, the ambient phosphomonoester pool will be critical to supporting planktonic biomass and production.

Although the proportion of ELFA cells significantly increased in the $+\mathrm{N}$ treatment of both experiments, it reached the highest values at Sta. A, the station with the lowest DIP concentration. Previous studies have tried to find a threshold value in DIP concentrations where APA would be stimulated above the constitutive level. Results vary according to studied areas and methods (Sebastián et al. 2004; Dyhrman and Ruttenberg 2006; Nedoma et al. 2006) and require many measurements in a broad range of 
DIP concentrations to be able to accurately identify a threshold for a given system or season, if there is one. Results from ELF labeling showed that a majority of the activity was due to picophytoplankton cells (likely Synechococcus). Although some larger $(>2 \mu \mathrm{m})$ phytoplankton cells (mostly diatoms and dinoflagellates, data not shown) were also labeled, the cell abundance on the filters was not high enough to provide reliable results. Nevertheless, the presence of APA associated with these populations is consistent with previous work in both open ocean and coastal systems (Lomas et al. 2004; Dyhrman and Ruttenberg 2006). Larger sample volumes would be necessary to examine the regulation patterns of large phytoplankton for the NPSG. In the 5-d shipboard incubation experiments, the proportion of ELFA-labeled picophytoplankton cells (likely Synechococcus) increased in the $+\mathrm{N}$ treatment, reaching $95 \% \pm 9 \%$ and $50 \% \pm 3 \%$ at Sta. A and Sta. D (Fig. 3D,H), respectively, whereas only a small percentage $(<4.5 \%)$ of the cells in the heterotrophic bacteria-enriched fraction was ELFA labeled (Fig. 3C,G). This fraction contained Prochlorococcus cells, which were not distinguishable from the heterotrophic bacteria by epifluorescence microscopy. Neither can we assign a lower detection limit for APA by the ELFA labeling procedure. For these reasons, the estimations of ELFA-labeled heterotrophic bacteria may be biased. Moreover, we cannot conclusively comment on the labeling of the Prochlorococcus populations. Nevertheless, using flow cytometry, Duhamel et al. (2008) showed that Prochlorococcus cells were not significantly ELFA labeled in the P-limited Mediterranean Sea. A similar application of flow cytometry to study cellspecific APA of Prochlorococcus populations in other Plimited areas would be a fruitful area of future research. These results emphasize the response capacity of the Synechococcus-like cells to changes in $\mathrm{P}$ demand, with essentially all the cells producing APA. In other oligotrophic environments, authors rarely observed ELFA-labeled picophytoplankton, whereas larger cells, such as diatoms, dinoflagellates, and autotrophic flagellates, showed high ELFA labeling during low $\mathrm{P}$ concentration periods of the year (Lomas et al. 2004; Mackey et al. 2007). However, they used a cell membrane permeabilization step with $70 \%$ ethanol, which may damage the cells and fade Chl $a$, making these small cells difficult or even impossible to identify by epifluorescence microscopy (Nedoma et al. 2003).

The low percentage of ELFA-labeled cells in the heterotrophic bacteria-enriched fraction is surprising compared to the percentages reached for the picophytoplankton-enriched fraction, whereas total APA values were in the same order of magnitude for each fraction. However, the APA rates were assayed at a saturating substrate concentration, and represent maximum potential rates. Kinetic studies on size-fractionated samples in this environment would be useful in the context of further work to better characterize the competitive capacities of each fraction. Although there are very few studies dealing with heterotrophic bacteria cell-specific APA in the marine environment, previous results also showed very low percentages $(<5 \%)$ of ELFA-labeled heterotrophic bacteria in oligo- trophic P-limited marine waters (Duhamel et al. 2008; Van Wambeke et al. 2008). Moreover, previous studies showed that although Prochlorococcus grown in low-P medium exhibit ELFA labeling, natural populations lacked ELFA labeling even in very-low-P environments (Mackey et al. 2007; Duhamel et al. 2008). Thus, even under a range of $P$ concentrations in different systems, the proportion of heterotrophic bacteria and Prochlorococcus with APA is very low compared to the larger phytoplankton. We present several hypotheses to explain these low percentages. The first hypothesis would be the detection limit of the method. Considering the size of heterotrophic bacteria and Prochlorococcus cells compared to larger phytoplankton cells, the amount of ELFA precipitate per cell is very small and may be undetectable by epifluorescence microscopy. For example, Van Wambeke et al. (2008) showed that below a threshold of 5-10 nmol MUF-P hydrolyzed $\mathrm{L}^{-1} \mathrm{~h}^{-1}$ (i.e., higher rates than in our samples; Table 1; Fig. 3); there was no significant relationship between the distribution of ELFA-labeled cells vs. MUF-P-based APA. The second hypothesis is that heterotrophic bacteria and Prochlorococcus cells could respond differently than larger phytoplankton cells to the ELFA-labeling method. Indeed, ELFP is a substrate analogue to phosphomonoester, but considering the number of phosphomonoester compounds, it is possible that most heterotrophic bacteria and Prochlorococcus do not use all the phosphomonoester compounds and would not hydrolyze the ELFP as a substrate. It is possible that cellsurface localization of the enzyme for most of these cells does not allow the intracellular precipitate to be formed or that they excrete their enzymes, which would be consistent with the high dissolved activity sometimes measured in the ocean. Indeed, a recent metagenomic analysis predicted that up to $41 \%$ and $30 \%$ of marine bacterial AP are cytoplasmic and extracellular, respectively (Luo et al. 2009). An additional explanation is that only a subset of the heterotrophic bacteria is metabolically active and thus the percentage of ELFA-labeled cells is depressed relative to the picophytoplankton. In the South Pacific Subtropical Gyre, the fraction of active cells accounts for roughly $25 \%$ of DAPI-stained cells in surface waters (Obernosterer et al. 2008). If the same range of active heterotrophic bacteria can be applied to the NPSG, then the proportion of active bacteria ELFA-labeled would be 4 times higher than the values estimated from total bacterial abundances (i.e., $17.4 \%$ for the highest value). It is also possible that most heterotrophic bacteria and Prochlorococcus rely on enzymes other than AP to access the DOP pool (e.g., 5'-nucleotidase, phosphonatase, adenosine-5'triphosphatases). Finally, in a given habitat, even if DIP is below the detection limit of the available methods, there may still be a finite even large flux of $P$ given the fact that most of the daily production in oligotrophic ecosystems is supported by recycled nutrients. Under conditions of extreme competition for DIP, smaller cells would be favored, and perhaps heterotrophic bacteria and Prochlorococcus populations force larger phytoplankton populations, such as Synechococcus, to use other bioavailable $\mathrm{P}$ compounds as predicted by resource partitioning theory.

The size fractionation of our samples allows us to estimate the proportion of APA due to the dissolved 


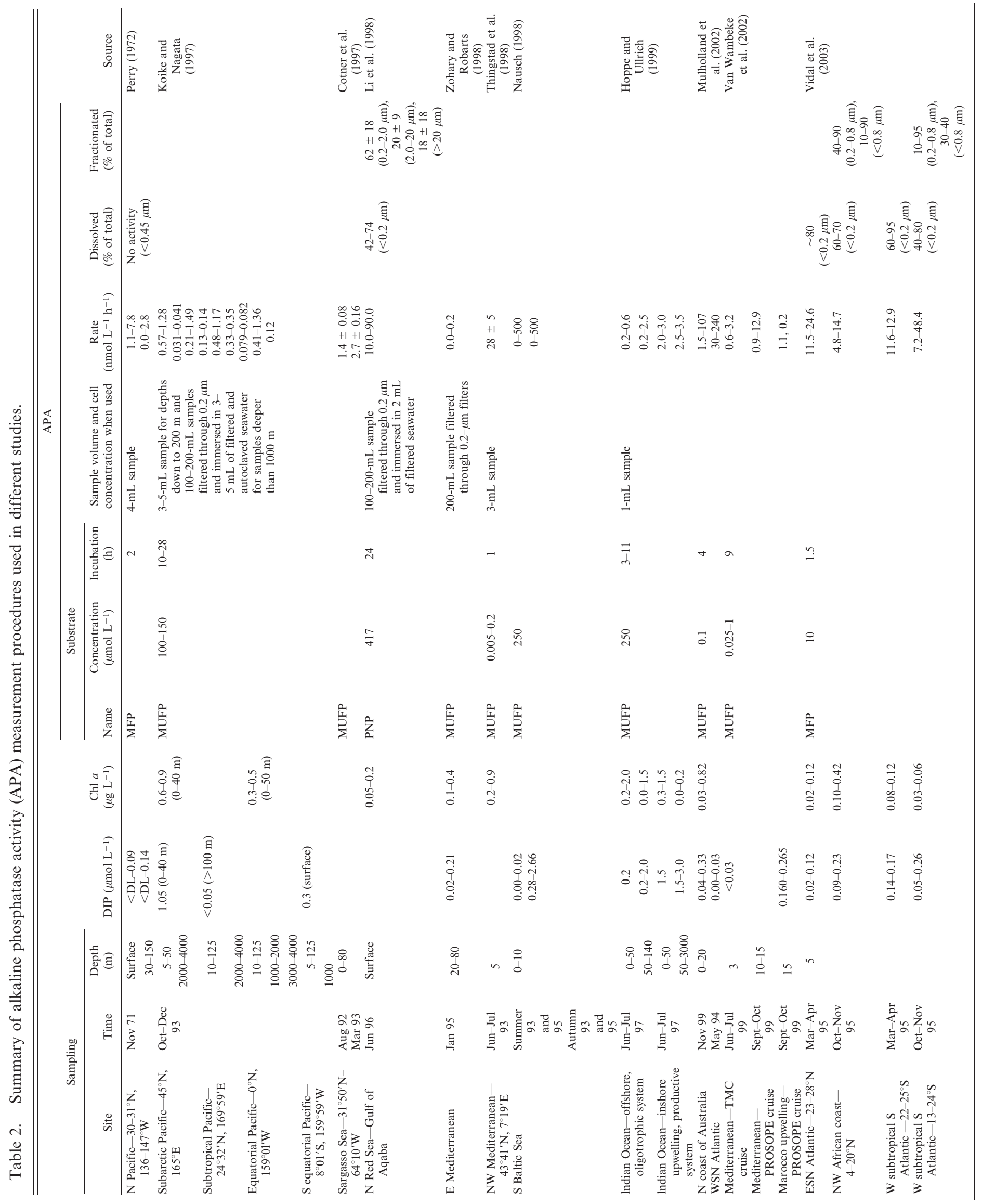




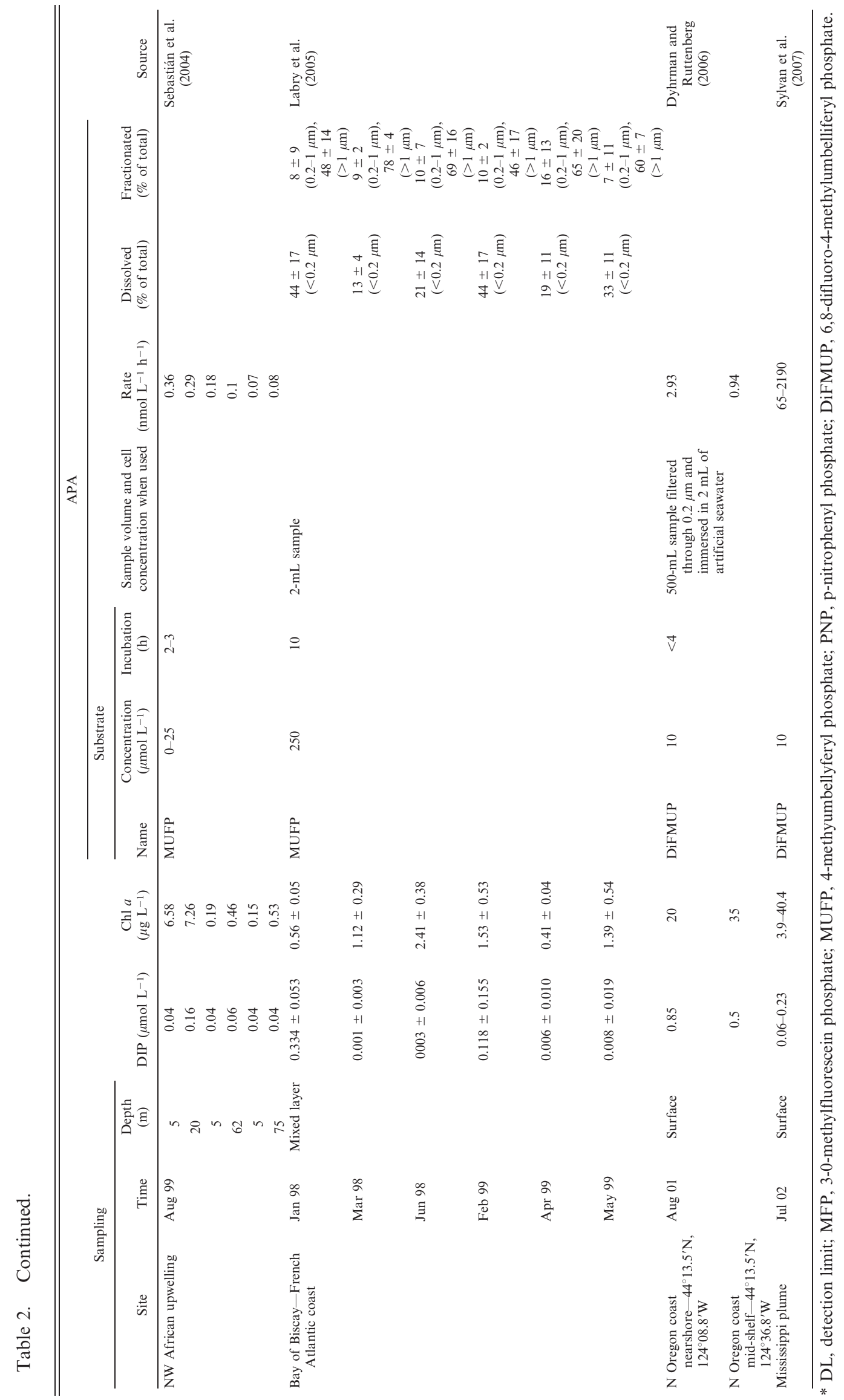


fraction $(<0.2-\mu \mathrm{m})$. The pool of "free dissolved" phosphatases in the sea is still fairly unexplored (Hoppe 2003; Table 2). In our study, the majority of total APA was due to the dissolved fraction $(75 \% \pm 4 \%$ and $141 \% \pm 18 \%$ for Sta. A and Sta. D, respectively), which can explain the low percentages of ELFA-labeled cells (Fig. 3) obtained at the corresponding stations in the initial samples. Even though information on dissolved APA is scarce, other studies showed that the dissolved APA represents a significant part of the total activity. For example, Labry et al. (2005) reported that dissolved APA represented 13\% to $44 \%$ of the total APA in the Bay of Biscay (on the French Atlantic coast). Higher proportions were recorded in the northern Red Sea (42-74\%; Li et al. 1998). These observations of dissolved activity are supported by a recent metagenomic analysis that predicted that up to $30 \%$ of marine bacterial AP enzymes are extracellular (Luo et al. 2009). Dissolved activity represents a mixture of enzymes of different origins, such as phagotrophy of protozoa and release of macromolecular organic compounds by heterotrophic marine nanoflagellates (Hoppe 2003). However, little is known about the ecological significance of this process. The study of dissolved APA origin and ecological role in aquatic ecosystems would be a significant area of future research. The pool of free dissolved phosphatases was very high throughout the duration of the nutrient addition experiments in all treatments and could reach values higher than $100 \%$ of the total APA, underlining methodological issues linked to the filtration step. Indeed, even under low vacuum $(<$ $20 \mathrm{kPa}$ ), the cells might lyse and liberate intracellular phosphatases, which would increase our measurements of APA. Interestingly, the proportion of dissolved activity decreased in the $+\mathrm{N}$ treatment (mainly due to the increase in particulate APA), whereas the percentage of ELFAlabeled cells increased, indicating that the microbial assemblage shifted from a free dissolved phosphatasesdominated system under $\mathrm{N}$ limitation and $\mathrm{P}$ stress to a "phytoplankton-cell-attached" phosphatase-dominated system under P limitation.

This study highlights that the capacity for DOP hydrolysis can differ substantially between heterotrophic bacteria and picophytoplankton groups in the same systems. Our results suggest that picophytoplankton, which is responsible for a majority of primary production in oligotrophic systems, may be influenced by DOP bioavailability in low-P environments, and that Synechococcus populations could sustain their P need by hydrolyzing DOP through APA. Heterotrophic bacteria and Prochlorococcus populations, which compete with Synechococcus for DIP, seem to rely on other strategies to meet their P requirements. Further work on the DOP pool composition and bioavailability in the oligotrophic gyres is a prerequisite for better understanding how this nutrient reservoir influences open ocean production and plankton community structure. Moreover, considering the increasing number of studies predicting the future ocean biogeochemistry evolving toward $\mathrm{P}$ stress and possibly $\mathrm{P}$ limitation (Karl et al. 2001; Barcelos e Ramos et al. 2007; Hutchins et al. 2007), it is essential to better characterize the mechanisms used by microorganisms to fulfill their $\mathrm{P}$ demand and to evaluate to what extent DOP can sustain primary production in low-P marine environments.

\section{Acknowledgments}

We thank Mark Brzezinski, the chief scientist of the Pacific Open Ocean Bloom cruise; the captain and crew of the R/V Kilo Moana and numerous colleagues in the Center for Microbial Oceanography: Research and Education; Cara Wilson, Karin Björkman, and Ken Doggett for valuable discussions; and the reviewers for constructive suggestions. Funds for this work were provided by the Gordon and Betty Moore Foundation (D.M.K.) and the National Science Foundation (D.M.K. and S.T.D.).

\section{References}

Agawin, N. S. R., C. M. Duarte, and S. Agusti. 2000. Nutrient and temperature control of the contribution of picoplankton to phytoplankton biomass and production. Limnol. Oceanogr. 45: 591-600.

Agis, M., A. Granda, and J. R. Dolan. 2007. A cautionary note: Examples of possible microbial community dynamics in dilution grazing experiments. J. Exp. Mar. Biol. Ecol. 341: 176-183, doi:10.1016/j.jembe.2006.09.002

Barcelos e Ramos, J., H. Biswas, K. G. Schulz, J. Laroche, and U. RiEBeSELl. 2007. Effect of rising atmospheric carbon dioxide on the marine nitrogen fixer Trichodesmium. Global Biogeochem. Cycles 21: GB2028, doi:10.1029/2006GB002898

Beardall, J., E. Young, and S. Roberts. 2001. Approaches for determining phytoplankton nutrient limitation. Aquat. Sci. Res. Across Boundaries 63: 44-69.

Buörkman, K. M., A. L. Thomson-Bulldis, and D. M. Karl. 2000. Phosphorus dynamics in the North Pacific subtropical gyre. Aquat. Microb. Ecol. 22: 185-198, doi:10.3354/ ame022185

Cembella, A. D., N. J. Antia, and P. J. Harrison. 1984. The utilization of inorganic and organic phosphorus compounds as nutrients by eukaryotic microalgae: A multidisciplinary perspective: Part 1. Crit. Rev. Microbiol. 10: 317-391, doi:10.3109/10408418209113567

Cotner, J., J. W. Ammerman, E. R. Peele, and E. Bentzen. 1997. Phosphorus-limited bacterioplankton growth in the Sargasso Sea. Aquat. Microb. Ecol. 13: 141-149, doi:10.3354/ame013141

Duhamel, S., G. Gregori, F. Van Wambeke, R. Mauriac, and J. Nedoma. 2008. A method for analysing phosphatase activity in aquatic bacteria at the single cell level using flow cytometry. J. Microbiol. Methods 75: 269-278, doi:10.1016/j.mimet. 2008.06.018

- - , AND J. Nedoma. 2009. Detection of extracellular phosphatase activity at the single cell level by enzyme-labelled fluorescence and flow cytometry: The importance of time kinetics in ELFA labelling. Cytometry A 75A: 163-168, doi:10.1002/cyto.a.20686

Dyhrman, S. T., and K. C. Ruttenberg. 2006. Presence and regulation of alkaline phosphatase activity in eukaryotic phytoplankton from the coastal ocean: Implications for dissolved organic phosphorus remineralization. Limnol. Oceanogr. 51: 1381-1390.

Hammes, F., M. Vital, And T. Egli. 2010. A critical evaluation of the volumetric "bottle effect" on microbial batch growth. Appl. Environ. Microbiol. 76: 1278-1281, doi:10.1128/AEM.01914-09

Hoppe, H. G. 2003. Phosphatase activity in the sea. Hydrobiology 493: 187-200, doi:10.1023/A:1025453918247

, AND S. Ullrich. 1999. Profiles of ectoenzymes in the Indian Ocean: Phenomena of phosphatase activity in the mesopelagic zone. Aquat. Microb. Ecol. 19: 139-148, doi:10.3354/ame019139 
Hutchins, D. A., AND others. 2007. $\mathrm{CO}_{2}$ control of Trichodesmium $\mathrm{N}_{2}$ fixation, photosynthesis, growth rates, and elemental ratios: Implications for past, present, and future ocean biogeochemistry. Limnol. Oceanogr. 52: 1293-1304.

Johnson, D. L. 1971. Simultaneous determination of arsenate and phosphate in natural waters. Environ. Sci. Technol. 5: 411-414, doi:10.1021/es60052a005

Karl, D. M., AND K. BJörkman. 2002. Dynamics of DOP, p. 249 366. In D. A. Hansell and C. A. Carlson [eds.], Biogeochemistry of marine dissolved organic matter. Elsevier Science.

1999. A sea of change: Biogeochemical variability in the North Pacific Subtropical Gyre. Ecosystems 2: 181-214, doi:10.1007/s100219900068

. 2000. Phosphorus, the staff of life. Nature 406: 31-32, doi:10.1038/35017683

, R. R. Bidigare, and R. M. Letelier. 2001. Long-term changes in phytoplankton community structure and productivity in the North Subtropical Gyre: The domain shift hypothesis. Deep-Sea Res. II 48: 1449-1470, doi:10.1016/ S0967-0645(00)00149-1

—, AND G. TIEN. 1992. MAGIC: A sensitive and precise method for measuring dissolved phosphorus in aquatic environments. Limnol. Oceanogr. 37: 105-116.

Koike, I., And T. Nagata. 1997. High potential activity of extracellular alkaline phosphatase in deep waters of the central Pacific. Deep-Sea Res. II 44: 2283-2294, doi:10.1016/ S0967-0645(97)00025-8

Labry, C., D. Delmas, and A. Herbland. 2005. Phytoplankton and bacterial alkaline phosphatase activities in relation to phosphate and DOP availability within the Gironde plume waters (Bay of Biscay). J. Exp. Mar. Biol. Ecol. 318: 213-225, doi:10.1016/j.jembe.2004.12.017

Li, H., M. J. W. Veldhuis, And A. F. Post. 1998. Alkaline phosphatase activities among planktonic communities in the northern Red Sea. Mar. Ecol. Prog. Ser. 173: 107-115, doi:10.3354/meps 173107

Lomas, M. W., A. Swain, R. Shelton, and J. W. Ammerman. 2004. Taxonomic variability of phosphorus stress in Sargasso Sea phytoplankton. Limnol. Oceanogr. 49: 2303-2310.

Luo, H., R. Benner, R. A. Long, And J. Hu. 2009. Subcellular localization of marine bacterial alkaline phosphatases. Proc. Natl. Acad. Sci. USA 106: 21219-21223, doi:10.1073/ pnas.0907586106

Mackey, K. R. M., R. G. Labiosa, M. Calhoun, J. H. Street, A. F. Post, and A. Paytan. 2007. Phosphorus availability, phytoplankton community dynamics, and taxon-specific phosphorus status in the Gulf of Aqaba, Red Sea. Limnol. Oceanogr. 52: 873-885.

Marie, D., F. Partensky, N. Simon, L. Guillou, and D. Vaulot. 2000. Flow cytometry analysis of marine picoplankton, p. 421-454. In R. A. Diamond and S. DeMaggio [eds.], Living colors: Protocols in flow cytometry and cell sorting. Springer-Verlag.

Moutin, T., D. M. Karl, S. Duhamel, P. Rimmelin, P. Raimbault, B. A. S. Van Mooy, and H. Claustre. 2008. Phosphate availability and the ultimate control of new nitrogen input by nitrogen fixation in the tropical Pacific Ocean. Biogeosciences 5: 95-109.

Mulholland, M. R., S. Floge, E. J. Carpenter, and D. G. CAPONE. 2002. Phosphorus dynamics in cultures and natural populations of Trichodesmium spp. Mar. Ecol. Prog. Ser. 239: 45-55, doi:10.3354/meps239045

Murphy, J., AND J. Riley. 1962. A modified single solution method for the determination of phosphate in natural waters. Anal. Chim. Acta 27: 31-36, doi:10.1016/S0003-2670(00)88444-5
Nausch, M. 1998. Alkaline phosphatase activities and the relationship to inorganic phosphate in the Pomeranian Bight (southern Baltic Sea). Aquat. Microb. Ecol. 16: 87-94, doi:10.3354/ame016087

Nedoma, J., J. C. Garcia, M. Comerma, K. S̆mek, and J. ArMENGOL. 2006. Extracellular phosphatases in a Mediterranean reservoir: Seasonal, spatial and kinetic heterogeneity. Freshw. Biol. 51: 1264-1276, doi:10.1111/j.1365-2427.2006.01566.x

- A. Štrojsová, J. Vrba, J. Komárková, and K. Šimek. 2003. Extracellular phosphatase activity of natural plankton studied with ELF97 phosphate: Fluorescence quantification and labelling kinetics. Environ. Microbiol. 5: 462-472, doi:10.1046/j.1462-2920.2003.00431.x

Obernosterer, I., AND others. 2008. Biochemical characteristics and bacterial community structure of the sea surface microlayer in the South Pacific Ocean. Biogeosciences 5: 693-705.

Orrett, K., and D. M. Karl. 1987. Dissolved organic phosphorus production in surface seawaters. Limnol. Oceanogr. 32: 383-395.

Perry, M. J. 1972. Alkaline phosphatase activity in subtropical Central North Pacific waters using a sensitive fluorometric method. Mar. Biol. 15: 113-119, doi:10.1007/BF00353639

Ryther, J. H. 1969. Photosynthesis and fish production in the sea. Science 166: 72-76, doi:10.1126/science.166.3901.72

Sebastián, M., J. Arístegui, M. F. Montero, J. Escanez, and F. XAvier Niell. 2004. Alkaline phosphatase activity and its relationship to inorganic phosphorus in the transition zone of the North-western African upwelling system. Prog. Oceanogr. 62: 131-150, doi:10.1016/j.pocean.2004.07.007

Strickland, J. D. H., and T. R. Parsons. 1972. A practical handbook of seawater analysis, 2nd ed. Bull. Fish. Res. Board Can. 167: 139-140.

Sylvan, J. B., A. Quigg, S. Tozzi, and J. W. Ammerman. 2007. Eutrophication-induced phosphorus limitation in the Mississippi River plume: Evidence from fast repetition rate fluorometry. Limnol. Oceanogr. 52: 2679-2685.

Thingstad, T. F., U. L. Zweifel, and F. Rassoulzadegan. 1998. $\mathrm{P}$ limitation of heterotrophic bacteria and phytoplankton in the northwest Mediterranean. Limnol. Oceanogr. 43: 88-94.

Van Wambeke, F., U. Christaki, A. Giannakourou, T. Moutin, AND K. Souvemerzoglou. 2002. Longitudinal and vertical trends of bacterial limitation by phosphorus and carbon in the Mediterranean Sea. Microb. Ecol. 43: 119-133, doi:10.1007/ s00248-001-0038-4

-, J. Nedoma, S. Duhamel, and P. Lebaron. 2008. Alkaline phosphatase activity studied with ELF97 phosphate: Success and limits in P-limited Mediterranean Sea. Aquat. Microb. Ecol. 52: 245-251, doi:10.3354/ame01238

Vidal, M., C. M. Duarte, S. Agustí, J. M. Gasol, and D. VAQUÉ. 2003. Alkaline phosphatase activities in the central Atlantic Ocean indicate large areas with phosphorus deficiency. Mar. Ecol. Prog. Ser. 262: 43-53, doi:10.3354/meps 262043

Zobell, C. E. 1943. The effect of solid surfaces upon bacterial activity. J. Bacteriol. 46: 39-56.

Zohary, T., AND R. D. Robarts. 1998. Experimental study of microbial P limitation in the eastern Mediterranean. Limnol. Oceanogr. 43: 387-395.

Associate editor: Mikhail V. Zubkov

Received: 08 September 2009 Accepted: 03 January 2010 Amended: 25 February 2010 